\title{
Prediction of biological sensors appearance with ARIMA models as a tool for Integrated Pest Management protocols
}

\author{
María Fernández-González', David Ramos-Valcárcel², María Jesús Aira³, \\ Francisco Javier Rodríguez-Rajo' \\ ${ }^{1}$ Department of Plant Biology and Soil Sciences, Sciences Faculty of Ourense, University of Vigo, Ourense, Spain \\ 2 Department of Informatics, University of Vigo, Ourense, Spain \\ ${ }^{3}$ Department of Botany, Pharmacy Faculty, University of Santiago of Compostela, Santiago of Compostela, Spain
}

Fernández-González M, Ramos-Valcárcel D, Jesús Aira M, Rodríguez-Rajo FJ. Prediction of biological sensors appearance with ARIMA models as a tool for Integrated Pest Management protocols. Ann Agric Environ Med. 2016; 23(1): 129-137. doi: 10.5604/12321966.1196868

\begin{abstract}
Introduction and objectives. Powdery mildew caused by Uncinula necator and Downy mildew produced by Plasmopara viticola are the most common diseases in the North-West Spain vineyards. Knowledge of airborne spore concentrations could be a useful tool in the Integrated Pest Management protocols in order to reduce the number of pesticide treatments, applied only when there is a real risk of infection.

Material and methods. The study was carried out in a vineyard of the D. O. Ribeiro, in the North-West Spain, during the grapevine active period 2004-2012. A Hirts-type volumetric spore-trap was used for the aerobiological monitoring.

Results. During the study period the annual total U. necator spores amount ranged from the 578 spores registered in 2007 to the 4,145 spores sampled during 2008. The highest annual total $P$. viticola spores quantity was observed in 2010 (1,548 spores) and the lowest in 2005 (210 spores). In order to forecast the concentration of fungal spores, ARIMA models were elaborated.

Conclusions. The most accurate models were an ARIMA (3.1.3) for U. necator and (1.0.3) for P. viticola. The possibility to forecast the spore presence 72 hours in advance open an important horizon for optimizing the organization of the harvest processes in the vineyard.
\end{abstract}

\section{Key words}

Agronomy, ARIMA, Integrated Pest Management, phytopatology, Plasmopara viticola, Uncinula necator

\section{INTRODUCTION}

The most serious fungal diseases in grape-growing areas throughout the world are Powdery and Downy mildew, both caused by Uncinula necator ((Schwein.) Burrill) and Plasmopara viticola (Burk. \& Curt.) Berl. \& de Toni, respectively. The complex interactions between the pathogens/ plant phenology, chemical fungicide applications and the main meteorological parameters vary throughout the disease cycle. The integration of these parameters into agronomical models allow the forecasting of high spore concentration presence and, consequently, the critical disease risk periods $[1,2]$.

The epidemics produced by U. necator can progress rapidly during the entire growing season due to the recurrence of primary (sexual) and secondary (asexual) infections. The ascocarps are able to release ascospores in autumn, to survive over winter as a mycelium in buds, and to release viable spores in the following spring [3]. These ascospores are repeatedly discharged from the overwintered chasmothecia, causing discrete small spots on the abaxial surfaces of the shoots basal leaves [4]. Once these initial colonies are settled down in the plant, the fungus can asexually propagate via large numbers of conidia that disperse and infect additional leaves [5]. The

Address for correspondence: María Fernández-González Department of Plant Biology and Soil Sciences, Sciences Faculty of Ourense, University of Vigo, E-32004 Ourense, Spain

E-mail:mfgonzalez@uvigo.es

Received: 02 September 2013; accepted: 20 November 2014 flowers and berries are highly susceptible to infection from the Inflorescence emerge phenological stage to the Fruit set or the moment that the berries reach $8^{\circ}$ Brix [6].

$P$. viticola epidemics involve primary (sexual) and secondary (asexual) infection cycles. Oospores (sexual stage) overwinter in leaf debris or pruned canes in soil. In spring, they germinate developing a macrosporangium that releases the zoospores responsible of the primary infections on grape leaves and bunches [7]. The early infections are therefore followed by successive asexual cycles [8]. Thereafter, primary and secondary infections overlap during the vine vegetative cycle. Taking into account the $\mathrm{BBCH}$ scale [9], the more susceptible phenological stages to the oospores germination are the phase 09 of the principal growth stage 0 (sprouting), and the early phases of the stage 1 (leaf development) [10]. Recent studies have demonstrated a continuous succession of downy mildew risk period infections from May - August [7].

Traditionally, chemical control of the fungus was conducted by means of established calendars. The majority are ineffective, despite the high quantity of fungicide applications performed with the aim of ensuring the quality of the grape bunches and harvest [11] without considering the environmental risks and economic losses for winegrowers [2]. In recent years, there have been many efforts to develop simulation models that enable pathogen development by mean regression models, mechanistic [12], neural networks. The aim of this study is to develop an accurate ARIMA (Autorregresive Integrated Model of Running Mean) time series model in order to forecast the U. necator and P. viticola 
risk period attacks in the Designation of Origin Ribeiro area which would allow a reduction in the number of pesticide treatments.

\section{MATERIALS AND METHOD}

The study was conducted in a vineyard located in Cenlle, located in Ourense Province of the Ribeiro region of northwest Spain (Fig. 1). This region is characterized by fairly steep valleys and hillsides (altitude $75-400 \mathrm{~m}$ ).

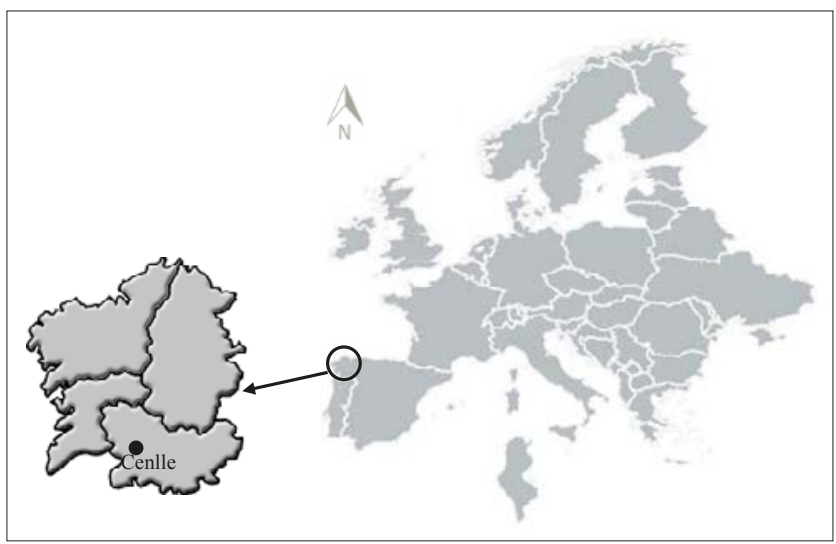

Figure 1. Location of Cenlle in the D.O. Ribeiro region of north-west Spain

Airborne fungal propagule concentrations were determined using a Lanzoni VPPS-2000 spore trap located in the central part of the vineyard from 2004-2012. The sampler was placed $2 \mathrm{~m}$ above ground level. Spores were counted following the model proposed by the Spanish Aerobiological Network (REA) [13].

The phenological study was carried out during the active grapevine season and determined using the BBCH scale [9]. A total of 60 selected plants were monitored. The sampling area was visited weekly, except during the flowering stage, when the visits increased to twice a week.

Meteorological data were obtained from a Hobo Micro Station data logger, located in the vineyard. The parameters monitored were temperature (maximum, minimum and mean), dew point and relative humidity. Information about rainfall was registered by means of a Davids weather station (Fig. 2).

In order to assess the degree of association between airborne spore concentrations and the main weather parameters a Spearman correlation test was conducted for the same day and the previous 1-7 days (period of time considered necessary to complete a disease cycle from sporulation to infection). Significance was calculated for $\mathrm{p} \leq 0.05$ and $\mathrm{p} \leq 0.01$. Finally, to forecast the $U$. necator and $P$. viticola spores concentrations an ARIMA (Autorregresive Integrated Model of Running Mean) time series model was developed. As estimators, the meteorological variables displaying the highest positive correlation coefficients and the spore concentrations for the previous days were selected. In addiction, the chemical treatments applied to the plants of the vineyard were taken into consideration. Therefore, to develop the ARIMA model, the 5 days after the fungicide application were not included in the training model data set from 2004-2010. The ARIMA model developed was tested with the data of 2011 and 2012, years not included in the training data set. With the aim of a statistical validation of the proposed ARIMA models predictive ability, a dependent samples t-test was carried out between the real and predicted data. All statistical analyses were conducted by means the SPSS 19.0 and the Statistica 7.0 software packages, as well as specially designed software.

\section{RESULTS}

During the study period, the annual total $U$. necator spores amount ranged from the 578 spores registered in 2007 to the 4,145 spores sampled during 2008 . The highest annual total P. viticola spores quantity was observed in 2010 (1548 spores), and the lowest in 2005 (210 spores) (Tab. 1). The most important $U$. necator spore incidence period was recorded during the months of May, June and July, whilst for P. viticola at the start (March, April and May) and the end (August and September) of the vegetative grapevine cycle (Fig. 3). From the beginning of the stage 1 (leaf development) until to the harvest, the longest vine life cycle (177 days) was registered during 2009, while the shortest was observed in 2010 (153 days). Analyzing the duration of the principal stages, it was noted that the longest stage was the development of fruits (stage 7), while the shortest was the flowering stage (stage 6) in all study years (Tab. 1).

The highest $U$. necator concentrations were recorded during the principal stages 6 (flowering) and 7 (development of fruits), although in 2006 they were advanced to stage 5 (inflorescence emergence). Likewise, the daily mean peak spores concentrations were observed during the principal stage 6 (flowering), mainly when intermittent rainfall periods of 2-3 consecutive days followed by 5-6 days with mean temperatures around $18^{\circ} \mathrm{C}$ were recorded (Fig. 2, 3). The $P$. viticola highest concentrations were recorded during the early principal stage 1 (leaf development), stage 5 (inflorescence emergence) and in the final stage of ripening of the grapes (stage 8 ). Moreover, the highest daily mean peak spores concentrations were registered in 2010, coinciding with stage 0 (sprouting) and recording secondary peaks during stage 7 (development of fruits), when intermittent rainfall accompanied by temperatures around $21^{\circ} \mathrm{C}$ were recorded (Fig. 2, 3).

With the aim of ascertaining the effects of the main weather parameters on the pathogens atmospheric concentrations, Spearman's lineal correlation analysis (R) was applied. Table 2 shows the statistical results. For the U. necator spore airborne presence, the most important parameters were the spore concentration of the 1-7 previous days, and the maximum, minimum and average temperature of the same day and the previous 1-7 days (positive sign and $p$ value $<0.001)$. For the presence of the $P$. viticola spores in the atmosphere, the most influential parameters were the spores concentration from the previous 1-7 days, and the maximum, minimum and average temperature of the same day and 1-7 previous days, while the rainfall of the same day induced the most important decreases of the Plasmopara spores in the atmosphere of the vineyard (Tab. 2).

Taking into account the afore-mentioned correlation results, two forecasting ARIMA models were obtained (Tab. 3). The most accurate model for U. necator was an ARIMA (3.1.3) including the average temperature of the same day as an independent variable. This model is able to predict the $U$. necator spores concentration with a 


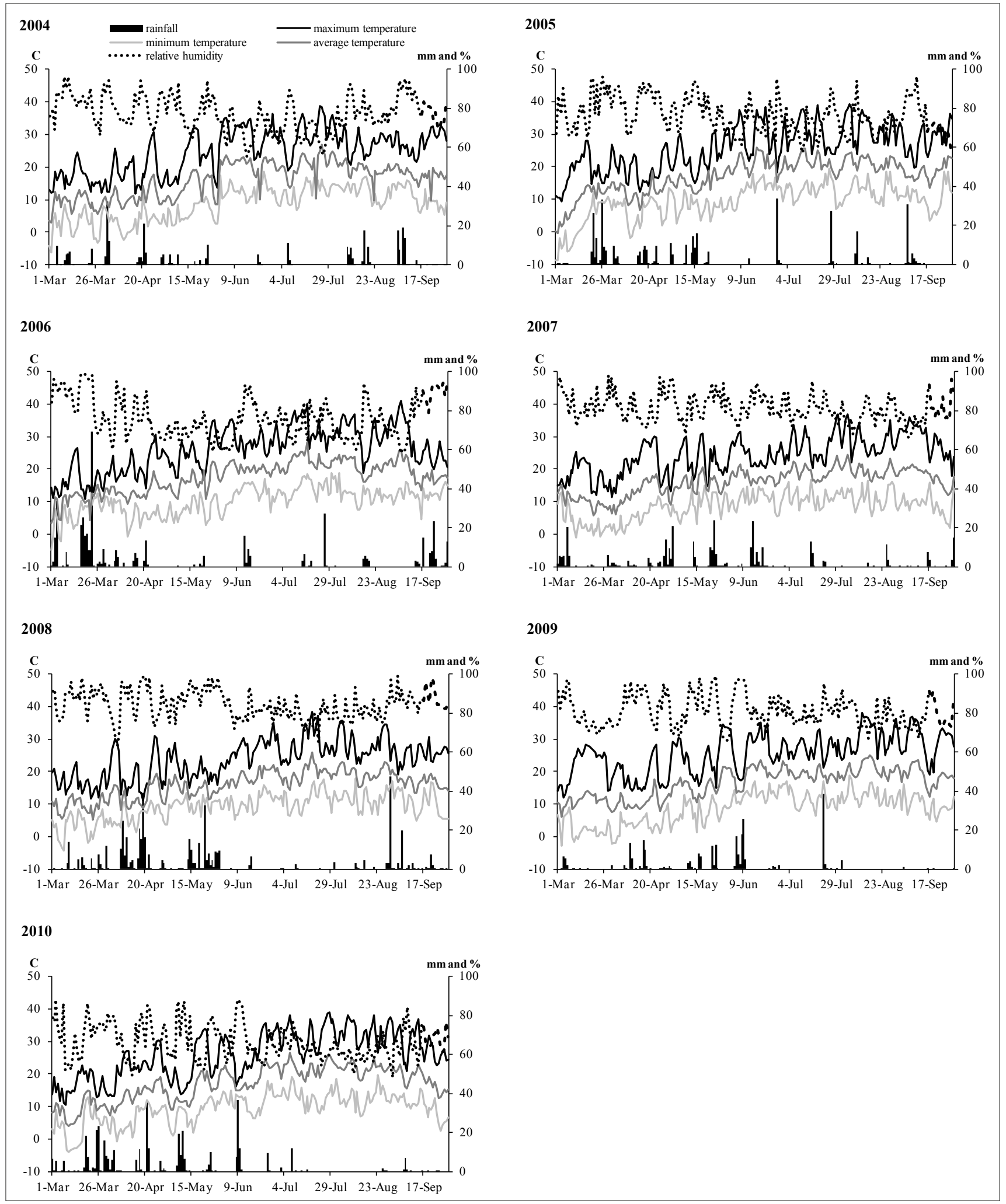

Figure 2. Evolution of the main meteorological parameters during the study period. Lines showing maximum, minimum and average temperature and relative humidity, in bars showing rainfall 
132

Annals of Agricultural and Environmental Medicine 2016, Vol 23, No 1

Maria Fernández-González, David Ramos-Valcárcel, Maria Jesús Ara, Francisco Javier Rodríguez-Rajo. Prediction of biological sensors appearance with ARIMA models...

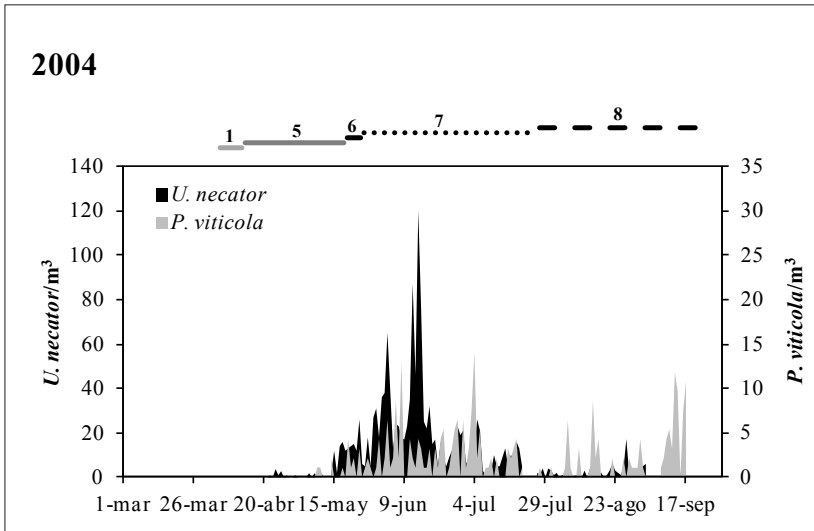

2006

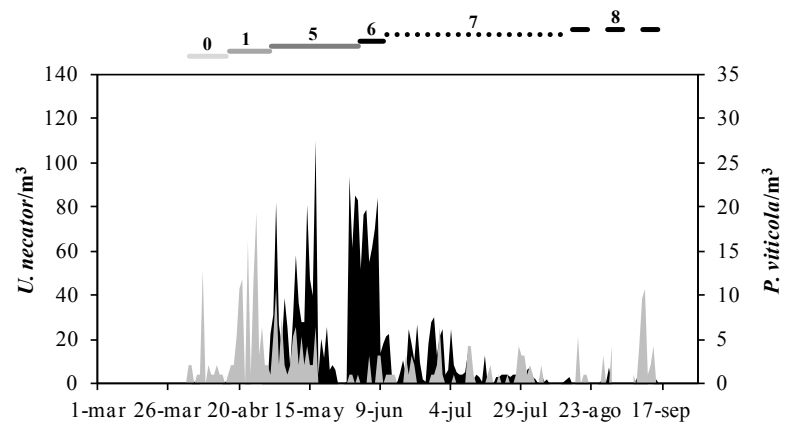

2008

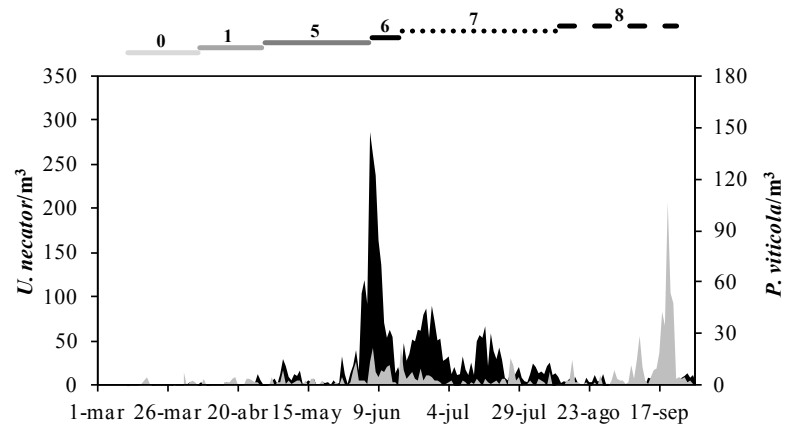

2005
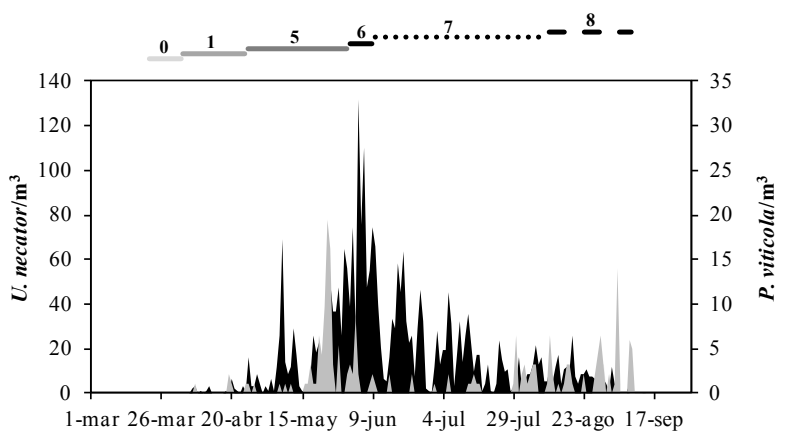

2007
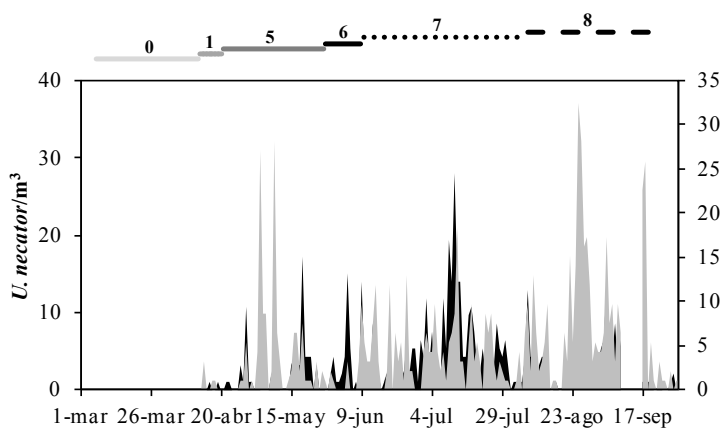

2009

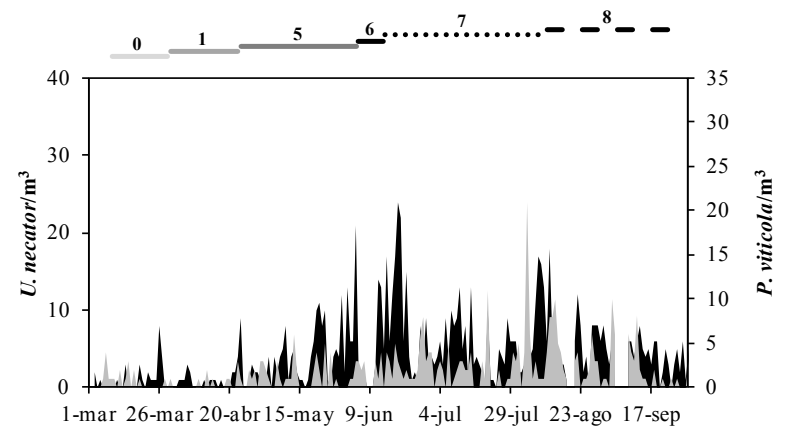

2010

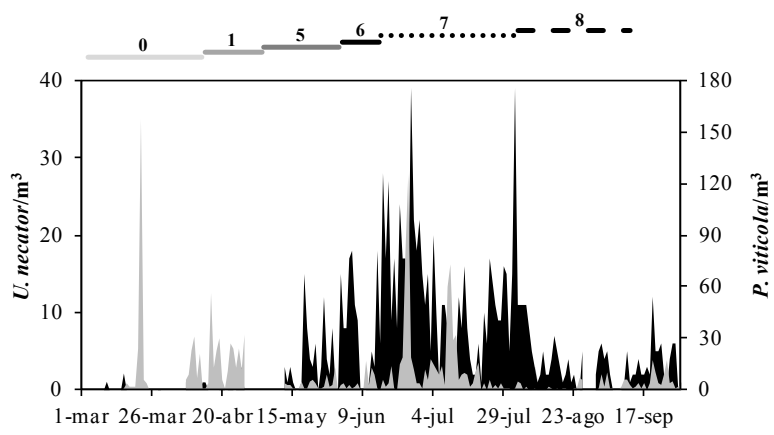

Figure 3. Evolution of Uncinula necator and Plasmopara viticola spores concentration and phonological growth stages: stage 0 - sprouting); stage 1 - leaf development; stage 5 - inflorescence emergence; stage 6 - flowering; stage 7 - development of fruits; stage 8 - ripening of berries 
Table 1. Start date, length, U. necator and $P$. viticola spores concentrations (daily and total values), maximum concentration and day during the each phenological stage: stage 0 - sprouting; stage 1 - leaf development; stage 5 - inflorescence emergence; stage 6 - flowering; stage 7 -development of fruits; stage 8 - ripening of berries

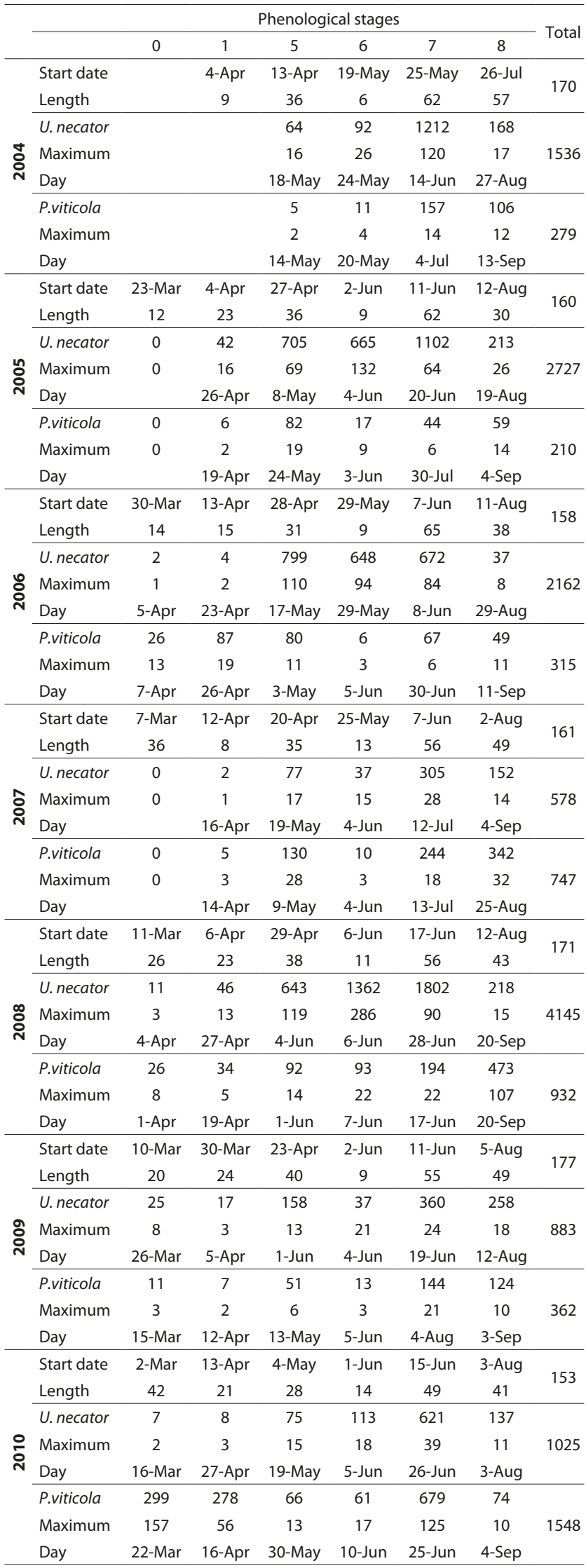

Table 2. Spearman coefficient correlations between concentration of spores during study period and main meteorological variables $\left(^{* * *} \mathrm{p}<0.01\right.$; $\left.{ }^{* *} \mathrm{p}<0.05\right)$

\begin{tabular}{|c|c|c|c|}
\hline U. necator & 2004-2010 & P. viticola & 2004-2010 \\
\hline U. necator-1 & $0.755^{* * *}$ & P. viticola-1 & $0.490^{* * *}$ \\
\hline U. necator -2 & $0.695^{* * *}$ & P. viticola -2 & $0.410^{* * *}$ \\
\hline U. necator -3 & $0.629 * * *$ & P. viticola -3 & $0.347^{* * *}$ \\
\hline U. necator -4 & $0.601^{* * *}$ & P. viticola -4 & $0.313^{* * *}$ \\
\hline U. necator -5 & $0.569^{* * *}$ & P. viticola -5 & $0.304^{* * *}$ \\
\hline U. necator -6 & $0.549^{* * *}$ & P. viticola -6 & $0.339^{* * *}$ \\
\hline U. necator-7 & $0.521^{* * *}$ & P. viticola -7 & $0.305^{* * *}$ \\
\hline Maximum Temperature & $0.413^{* * *}$ & Maximum Temperature & $0.157^{* * *}$ \\
\hline Maximum Temp -1 & $0.415^{* * *}$ & Maximum Temp -1 & $0.122^{* * *}$ \\
\hline Maximum Temp -2 & $0.369^{* * *}$ & Maximum Temp -2 & $0.091^{* * *}$ \\
\hline Maximum Temp -3 & $0.324^{* * *}$ & Maximum Temp -3 & $0.061^{* *}$ \\
\hline Maximum Temp -4 & $0.307^{* * *}$ & Maximum Temp -4 & $0.071^{* *}$ \\
\hline Maximum Temp -5 & $0.280^{* * *}$ & Maximum Temp -5 & $0.064^{* *}$ \\
\hline Maximum Temp -6 & $0.244^{* * *}$ & Maximum Temp -6 & $0.066^{* *}$ \\
\hline Maximum Temp -7 & $0.223^{* * *}$ & Maximum Temp -7 & $0.068^{* *}$ \\
\hline Minimum Temperature & $0.285^{* * *}$ & Minimum Temperature & $0.130^{* * *}$ \\
\hline Minimum Temp -1 & $0.257^{* * *}$ & Minimum Temp -1 & $0.137^{* * *}$ \\
\hline Minimum Temp -2 & $0.256^{* * *}$ & Minimum Temp -2 & $0.138^{* * *}$ \\
\hline Minimum Temp -3 & $0.265^{* * *}$ & Minimum Temp -3 & $0.099^{* * *}$ \\
\hline Minimum Temp -4 & $0.263^{* * *}$ & Minimum Temp -4 & $0.092^{* * *}$ \\
\hline Minimum Temp -5 & $0.248^{* * *}$ & Minimum Temp -5 & $0.089^{* * *}$ \\
\hline Minimum Temp -6 & $0.243^{* * *}$ & Minimum Temp -6 & $0.072^{* *}$ \\
\hline Minimum Temp -7 & $0.221^{* * *}$ & Minimum Temp -7 & $0.057^{* *}$ \\
\hline Mean Temperature & $0.457^{* * *}$ & Mean Temperature & $0.156^{* * *}$ \\
\hline Mean Temp -1 & $0.439 * * *$ & Mean Temp -1 & $0.140^{* * *}$ \\
\hline Mean Temp -2 & $0.416^{* * *}$ & Mean Temp -2 & $0.126^{* * *}$ \\
\hline Mean Temp -3 & $0.381^{* * *}$ & Mean Temp -3 & $0.099^{* * *}$ \\
\hline Mean Temp -4 & $0.362^{* * *}$ & Mean Temp -4 & $0.088^{* * *}$ \\
\hline Mean Temp -5 & $0.331^{* * *}$ & Mean Temp -5 & $0.075^{* * *}$ \\
\hline Mean Temp -6 & $0.310^{* * *}$ & Mean Temp -6 & $0.082^{* * *}$ \\
\hline Mean Temp -7 & $0.286^{* * *}$ & Mean Temp -7 & $0.078^{* * *}$ \\
\hline Relative humidity & $-0.346^{* * *}$ & Relative humidity & $-0.060^{* *}$ \\
\hline Humidity -1 & $-0.335^{* * *}$ & Humidity -1 & -0.024 \\
\hline Humidity -2 & $-0.286^{* * *}$ & Humidity -2 & -0.013 \\
\hline Humidity -3 & $-0.257^{* * *}$ & Humidity -3 & -0.011 \\
\hline Humidity -4 & $-0.214 * * *$ & Humidity -4 & -0.023 \\
\hline Humidity -5 & $-0.186^{* * *}$ & Humidity -5 & -0.023 \\
\hline Humidity -6 & $-0.152^{* * *}$ & Humidity -6 & -0.017 \\
\hline Humidity -7 & $-0.127^{* *}$ & Humidity -7 & -0.018 \\
\hline Rainfall & $-0.246^{* * *}$ & Rainfall & $-0.107^{* * *}$ \\
\hline Rainfall -1 & $-0.242^{* * *}$ & Rainfall -1 & -0.041 \\
\hline Rainfall -2 & $-0.213^{* * *}$ & Rainfall -2 & 0.019 \\
\hline Rainfall -3 & $-0.167^{* * *}$ & Rainfall -3 & 0.014 \\
\hline Rainfall -4 & $-0.154^{* * *}$ & Rainfall -4 & 0.000 \\
\hline Rainfall -5 & $-0.126^{* * *}$ & Rainfall -5 & 0.000 \\
\hline Rainfall -6 & $-0.090^{* * *}$ & Rainfall -6 & 0.016 \\
\hline Rainfall -7 & $-0.068^{* * *}$ & Rainfall -7 & -0.014 \\
\hline
\end{tabular}




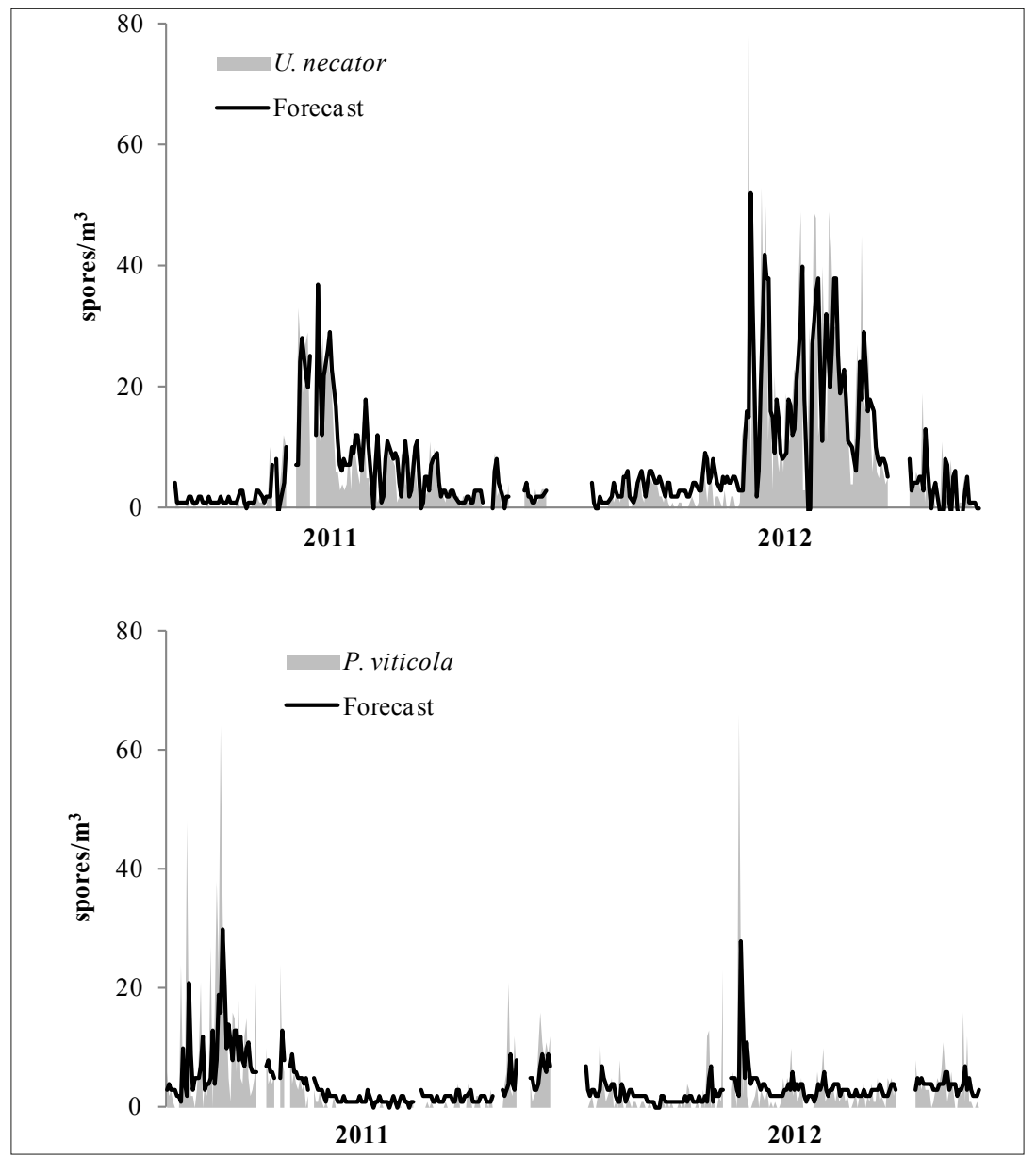

Figure 4. Daily mean $U$. necator and $P$. viticola spores concentrations observed and estimated during 2011-2012 testing the proposed ARIMA model.

Table 3. Time series of proposed ARIMA models for U. necator and P. viticola

\begin{tabular}{|c|c|c|c|c|}
\hline \multicolumn{5}{|l|}{ ARIMA (1.0.3) } \\
\hline \multirow[t]{2}{*}{ Adjusted $R^{2}=0.253$} & \multirow[b]{2}{*}{ B } & \multirow[b]{2}{*}{ ET } & \multicolumn{2}{|c|}{ P. viticola } \\
\hline & & & $\mathbf{t}$ & Sig. \\
\hline constant & -0.184 & 1.801 & -0.102 & 0.919 \\
\hline AR1 & 0.944 & 0.026 & 36.391 & 0.000 \\
\hline MA1 & 0.534 & 0.041 & 13.162 & 0.000 \\
\hline MA2 & 0.135 & 0.036 & 3.706 & 0.000 \\
\hline MA3 & 0.138 & 0.033 & 4.152 & 0.000 \\
\hline Maximum temperature & 0.146 & 0.063 & 2.328 & 0.020 \\
\hline \multicolumn{5}{|l|}{ ARIMA (3.1.3) } \\
\hline \multirow[t]{2}{*}{ Adjusted $R^{2}=0.686$} & & & \multicolumn{2}{|c|}{ U. necator } \\
\hline & B & ET & $\mathbf{t}$ & Sig. \\
\hline constant & 1.179 & 0.506 & 2.331 & 0.020 \\
\hline AR1 & 0.809 & 0.089 & 9.134 & 0.000 \\
\hline AR2 & -0.335 & 0.095 & -3.514 & 0.000 \\
\hline AR3 & 0.224 & 0.073 & 3.048 & 0.002 \\
\hline MA1 & 1.169 & 0.080 & 14.643 & 0.000 \\
\hline MA2 & -0.790 & 0.097 & -8.183 & 0.000 \\
\hline MA3 & 0.602 & 0.067 & 8.986 & 0.000 \\
\hline Mean temperature & -0.069 & 0.029 & -2.409 & 0.016 \\
\hline
\end{tabular}

Table 4. t-Test for U. necator and P. viticola spores concentration during 2011-2012 and estimated values from 2004-2010

\begin{tabular}{lccccccccc}
\hline & Mean & $\begin{array}{c}\text { Std. } \\
\text { Dv. }\end{array}$ & $\mathrm{N}$ & Diff. & $\begin{array}{c}\text { Std.Dv. } \\
\text { Diff }\end{array}$ & $\mathrm{t}$ & $\mathrm{df}$ & $\mathrm{p}$ \\
\hline $\begin{array}{l}\text { U. necator spores } \\
2011\end{array}$ & 5.077 & 6.958 & & & & & & \\
\hline Forecast & 5.677 & 6.821 & 155 & -0.6 & 5.314 & -1.406 & 154 & 0.162 \\
\hline $\begin{array}{l}\text { U. necator spores } \\
2012\end{array}$ & 9.288 & 13.297 & & & & & & \\
\hline Forecast & 9.529 & 10.657 & 170 & -0.241 & 10.735 & -0.293 & 169 & 0.770 \\
\hline $\begin{array}{l}\text { P. viticola spores } \\
2011\end{array}$ & 4.682 & 8.759 & & & & & & \\
\hline Forecast & 4.300 & 4.444 & 170 & 0.382 & 7.520 & 0.663 & 169 & 0.508 \\
\hline $\begin{array}{l}\text { P. viticola spores } \\
2012\end{array}$ & 2.833 & 5.889 & & & & & & \\
\hline Forecast & 3.102 & 2.563 & 186 & -0.269 & 5.904 & -0.621 & 185 & 0.535 \\
\hline
\end{tabular}

prediction horizon of 72 hours and a $\mathrm{R}^{2}$ value of 0.686 . For P. viticola, the most precise forecasting model was an ARIMA (1.0.3) including the maximum temperature of the same day as an independent variable. By means this model, the $P$. viticola spores concentration can be forecasted with a horizon prediction of 72 hours. The accuracy of the ARIMA models were evaluated by means the comparison of the predicted $U$. necator and P. viticola spores concentrations 
versus the observed values of the 2011 and 2012 years (Fig. 4) which were not included in the training data set of the models. In most cases, the predicted values matched actual spore counts. Moreover, the t-test of dependent samples conducted showed that there were no significant differences between observed and forecasted data (Tab. 4).

\section{DISCUSSION}

Knowledge about the concentration of the main phytopathogenic spores in a vineyard atmosphere could be a useful tool in the Integrated Pest Management protocols. The development of the disease symptoms on the plants can be related with the presence of the inoculums in the air some days in advance, as high airborne spore counts appeared linked to lesion density one week later [14]. Thus, the combination of biological sensors and meteorological parameters in the development of agrophenological models help into determining the periods of effective disease risk, thereby allowing a reduction in the number of chemical treatments applied to the plants.

In the presented study, the presence of airborne U. necator conidia and $P$. viticola sporangia was not constant throughout all the stages of the grapevine growing season. In addition, the specific fungicide application treatments also influenced the behaviour of the fungus cycle and the production of conidia and sporangia [2]. The synchronism between U. necator and $P$. viticola spores concentrations with the main phenological growth stages has been studied by several authors in different bioclimatical areas $[2,5,6]$.

Some authors indicate that the critical period for the Powdery mildew infection includes from the beginning of flowering until the berries reach $8^{\circ}$ Brix [6] or $7 \mathrm{~mm}$ in diameter [15]. Similar findings were obtained in the current study where the highest $U$. necator concentrations were mainly recorded during stage 7 (development of fruits). For a severe Powdery mildew infection it is necessary that some ascospores are deposited on a susceptible host surface in a period of time under favorable environmental conditions [16]. Moderate temperatures, limited direct sunlight and high humidity associated with rain events, induce the presence of $U$. necator spores in the vineyard, whereas the presence of free water is detrimental to conidial germination, causing some conidia lysis. UV radiation exposure reduces conidia germination or appressorium formation, and the subsequent colony expansion prolongs the latent period [3]. The most severe mildew epidemics are often produced in atypically rainy growing seasons, mainly related to rainy periods with cumulative rainfall $>2 \mathrm{~mm}$ or $>2.5 \mathrm{~mm}$ [17]. Moreover, temperature is another important factor promoting the ascospore dispersal; wet conditions associated with temperatures of $15-25^{\circ} \mathrm{C}$ [18] were stated as the optimum conditions. Temperatures below $8^{\circ} \mathrm{C}$ inhibit the processes of asexual reproduction of the fungus, as well as temperatures higher than $33^{\circ} \mathrm{C}[19,20]$. Finally, relative humidity between $76-96 \%$ is considered optimum for conidia germination and hyphen growth [20].

In the presented study, the maximum $U$. necator spore counts mainly coincided with favorable conditions for the conidia germination and spores dispersion: temperature variation between $17.5^{\circ} \mathrm{C}-21.8^{\circ} \mathrm{C}$, accompanied by alternating rainy-dry periods and relative humidity between $60-80 \%$. During 2009 and 2010, in the second half of July, the $U$. necator spores concentrations began to decrease due to the presence of moments of temperatures below the optimum values for the pathogen development for several consecutive days [19]. The disease is typically controlled by periodic applications of foliar fungicides, around 4-8 fungicide treatments during each growing season [16]. In the studied vineyard, the pesticide treatments ranged from 4 in 2004-9 in 2008. Despite the large number of treatments applied, 2008 was the year in which there was recorded a higher spore concentration, probably because many of them had been conducted at unsuitable moments. Even though fungicide schedules often recommend that applications should be conducted at fixed growth stages, usually the disease does not become evident until several weeks after its beginning when they are well advanced, and therefore the disease control it is difficult or impossible, even in the case of repeated applications of systemic fungicides being carried out [21]. These late treatments are ineffective because the primary ascosporic infection has finished and they have been applied at appropriate intervals for the control of secondary conidial infection [16]. This was the case in 2008 when the weather parameters also led to the spread of the fungus. The correlations with the meteorological variables showed that the temperature is the variable that best correlates with the concentration of $U$. necator spores, and therefore it was included in the model developed to predict the spore concentration.

The most accurate ARIMA model was the (3.1.3) taking into account the average temperature. The accuracy of the model was tested with data from the years 2011 and 2012 and a dependent samples t-test, registering a high similarity between the observed and estimated spore values. After a detailed analysis of the presented study, it is recommended that winegrowers should most appropriately administrate the phytosanitary treatments during the months of JuneJuly, and after rainy periods when the spores concentrations are higher than 10 spores $/ \mathrm{m}^{3}$. The presence of this spore threshold in the vineyard atmosphere could be a good biological indicator to assess the infection development in the study area one week later [14].

The presence of $P$. viticola sporangia was not continuous throughout the grapevine growing season. The highest $P$. viticola counts were recorded during the first principal phenological stages and mainly during the last stages 7 and 8 (development of fruit and ripening of berries, respectively). Similar findings were observed by Díaz [22] who stated that the most vulnerable stages in the disease development are stages 6 (flowering) and 7 (development of fruit). Recent studies have shown that the date of the primary $P$. viticola infections ranged between early May - mid-June [10]. It is considered that the primary infections depend on the temperature and rainfall, and the secondary infections are a function of the continuous presence of humidity and temperature on the leaves [1]. Raindrop size influences both the numbers of spores dispersed and the distance dispersed. In the case of $P$. viticola, the spore amount may be higher as a consequence of the larger drops generated by the impact of high raindrops during intense rainfall phenomena than in the case of small drops produced by less intense rainfall periods [23]. The optimum conditions for oospores germination occur in spring when rainfall is higher than $10 \mathrm{~mm}$ for 1-2 consecutive days, accompanied by temperatures above $10-12^{\circ} \mathrm{C}[12,24]$. The temperature 
is very important for the duration of the ripening period and the germination rate, the optimum temperature range being from $20^{\circ} \mathrm{C}-24^{\circ} \mathrm{C}[24]$. The presented study records high spores levels from the end of March - May during the phenological stages 0 (sprouting), stage 1 (leaf development) and stage 5 (inflorescence emergence), coinciding with a maximum temperature increase after a period of 2-3 days with rain. These findings are similar to those by Kennelly et al. [10] who found that the infection susceptible stages are the end of stage 0 (sprouting) and the first phases of stage 1 (leaf development). These high spore concentrations recorded during the early stages may be due to wintering oospores of the previous season leading to false positive for $P$. viticola, which has been noted by several authors $[7,10]$. Kennely et al. [10] showed that artificially inoculated leaves became infected at earlier growth stages, but the oospore cohorts that germinated during this period had a low density [12] so that the inoculum available for infection was low. The relative humidity has a decisive effect on sporulation and thus in the development of the disease. The optimum relative humidity ranges from $95 \%-100 \%$ [22]. Low relative humidity values associated with elevated temperatures during the day damage the survival of the sporangia [25]. This effect is evident in the current study during the summer months (July and August mainly) as during a large number of days the maximum temperature exceeded values of $30-35^{\circ} \mathrm{C}$ and relative humidity ranged between $53-83 \%$, which justify the low $P$. viticola spores concentration recorded. Otherwise, lower temperatures associated with higher relative humidity (ranging between 64-87\%) recorded during the same months in 2007 and 2009, could favour the P. viticola persistence in the vineyard and therefore the increased of the disease severity during these years. In the north of Italy, 7-10 fungicide treatments were conducted in order to maintain the vineyard under the economic disease threshold [12], a number similar to those conducted during the sampling period of the current study.

In view of the survivability $P$. viticola oospores during winter, for an effective Integrated Pest Management of the plague it would be important to avoid the presence of primary infections in the study vineyard. Therefore, in view of the experience acquired during this study, it is recommend that the winegrowers introduce some improvements in some cultural practices detected in vineyards in North-West Spain. Thus, the removal from the vineyard of the pruning shoots from the previous year was not carried out, which would have been an important source of primary inoculum. This would help reduce the number of subsequent treatments throughout growing vine cycle. In the presented study, to predict the spores concentration the weather variables that have the greatest influence were used. The most accurate ARIMA model developed was the (1.0.3) also taking into account the maximum temperature. The accuracy of the model was proved with the data of the years 2011 and 2012, and a big fit was registered between the observed and estimated data. Finally, the forecast behaviour of this model was statistically tested using a dependent samples t-test, which showed that there was no significant difference between the observed and predicted data.

\section{CONCLUSION}

The prediction of biological sensors appearance, such as the fitopathogenic spore concentration in the vineyard atmosphere, by means ARIMA time series model results in a useful tool in the Integrated pest Management protocols. The possibility to forecast the spore presence in the atmosphere of the vineyard 72 hours in advance, associated with the later requirement of one week for the induction of the disease symptoms on the plants, provides an important horizon for optimizing the organization of the harvest processes in the vineyard.

\section{Acknowledgements}

The study was financed by the Proyects INOU12-08 of the University of Vigo and the AGL2014-60412-R supported by the Ministry of Economy and Competitiveness of the Spanish Government

\section{REFERENCES}

1. Rosa M, Gozzini B, Orlandini S, Seghi, L. A computer program to improve the control of grapevine downy mildew. Comput Electron Agric. 1995; 12: 311-322.

2. Fernández-González M, Rodríguez-Rajo FJ, Jato V, Aira MJ. Incidence of fungals in a vineyard of the Denomination of Origin Ribeiro (Ourense-North-Western Spain). Ann Agr Environ Med. 2009; 16: 263-271.

3. Gadoury DM, Cadle-Davidson L, Wilcox WF, Dry IB, Seem RC, Milgroom MG. Grapevine powdery mildew (Erysiphe necator): a fascinating system for the study of the biology, ecology and epidemiology of an obligate biotroph. Molecular Plant Patholology. 2012; 13(1): 1-16.

4. Rossi V, Caffi T, Legler SE. Dynamics of ascospore maturation and discharge in Erysiphe necator, the causal agent of grape powdery mildew. Phytopathology. 2010; 100: 1321-1329.

5. Carisse O, Bacon R, Lefebvre A. Grape powdery mildew (Erysiphe necator) risk assessment based on airborne conidium concentration. Crop Prot. 2009; 28: 1036-1044.

6. Gadoury DM, Seem RC, Ficke A, Wilcox WF. Ontogenic resistance to powdery mildew in grape berries. Phytopathology. 2003; 93: 547-555.

7. Caffi T, Rossi V, Bugiani R, Spanna F, Flamini L, Cossu A, et al. A model predicting primary infections of Plasmopara viticola in different grapevine-growing areas of Italy. J Plant Pathol. 2009; 91(3): 535-548.

8. Blaeser M, Weltzien HC. Epidemiologische Studien an Plasmopara viticola zur Verbesserung der Spritzterminbestimmung. Zeitschrift für Pflanzenkrankheiten und Pflanzenschutz. 1979; 86: 489-98.

9. Meier U. Growth stages of mono and dicotyledonous plants. $\mathrm{BBCH}$ Monograph. 2nd ed. Federal Biological Research Centre for Agriculture and Forestry, 2001.

10. Kennelly MM, Gadoury DM, Wilcox WF, Magarey PA, Seem RC. Primary infection, lesion productivity, and survival of sporangia in the grapevine downy mildew pathogen Plasmopara viticola. Phytopathology. 2007; 97: 512-522.

11. Savary S, Delbac L, Rochas A, Taisant G, Willocquet L. Analysis of nonlinear relationships in dual epidemics, and its application to the management of grapevine downy and powdery mildews. Phytopathology. 2009; 99(8): 930-942.

12. Rossi V, Caffi T, Bugiani R, Spanna F, Della Valle D. Estimating the germination dynamics of Plasmopara viticola oosporas using hydrotermal time. Plant Pathology. 2008; 57: 216-226.

13. Galán Soldevilla C, Cariñanos González P, Alcázar Teno P, Domínguez Vilches E. Spanish Aerobiology Network (REA): Management and Quality Manual. University of Córdoba Publication Service, Córdoba, Spain, 2007.

14. Carisse O, Savary S, Willocquet L. Spatiotemporal relationships between disease development and airborne inoculum in unmanaged and managed Botrytis leaf blight epidemics. Phytopathology. 2008; 98: $38-44$.

15. Campbell P, Bendek C, Latorre BA. Risk of powdery mildew (Erysiphe necator) outbreaks on grapevines in relation to cluster development. Cienc Investig Agrar. 2007; 34 (1): 5-11. 
16. Caffi T, Rossi V, Legler SE, Bugiani R. A mechanistic model simulating ascosporic infections by Erysiphe necator, the powdery mildew fungus of grapevine. Plant Pathology. 2011; 60: 522-531.

17. Gadoury DM, Pearson RC. Ascocarp dehiscence and ascospore discharge in Uncinula necator. Phytopathology. 1990; 80: 393-401.

18. Jallioux F, Thind TS, Clerjeau M. Release, germination and pathogenicity of ascospores of Uncinula necator under controlled conditions. Canad J Botany. 1998; 76: 777-781.

19. Bendek C, Torres R, Campbell P, Latorre B. Aportes al conocimiento y control del oídio de la vid. Aconex (Chile). 2002; 76: 5-11.

20. Jarvis WR, Gubler WD, Grove GG. Epidemiology of powdery mildews in agricultural pathosystems. In: Bólanger RR, Bushnell WR, Dikana AJ, Timothy LW. The powdery Mildews a Comprehensive Treatise. St. Paul (Minnesota, USA) 2002. p. 166-199.
21. Sozzani F, Morando A, Lavezzaro S. Grapevine protection against powdery mildew in Piedmont: control of on-going infections. Atti Giornate Fitopatologiche. 2010; 2: 311-6.

22. Díaz MR. Aplicación de la Aerobiología en la agricultura. Control de enfermedades fúngicas y producción de Vitis vinifera. Thesis (PhD). University of Vigo. 1999.

23. Rossi V, Caffi T. The role of rain in dispersal of the primary inoculums of Plasmopara viticola. Phytopathology. 2012; 102: 158-165.

24. Laviola C, Burruano S, Strazzeri S. Influenza della temperatura sulla germinazione delle oospore di Plasmopara viticola (Berk. Et Curt.) Berl. Et De Toni. Phytopathology Mediterranea. 1986; 25: 80-84.

25. Lalancette N, Madden LV, Ellis MA. A quantitative model for describing the sporulation of Plasmopara viticola on grape leaves. Phytopathology. 1988; 78: 1316-1321. 